\title{
Analysis Of Carbon Emission Level on Merauke Regency Land Cover
}

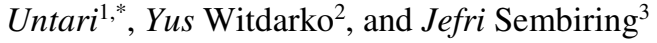 \\ ${ }^{1}$ Department of Agribusiness, Faculty of Agriculture, Musamus University, Merauke - Indonesia. \\ ${ }^{2}$ Department of Agricultural Techniques, Faculty of Agriculture, Musamus University, Merauke - Indonesia. \\ ${ }^{3}$ Department of Agrotechnology, Faculty of Agriculture, Musamus University, Merauke - Indonesia.
}

\begin{abstract}
This research is aimed to know level of carbon emission from land cover change in Merauke Regency. The data are historical baseline which is land cover map time series of 1990, 2000, 2005, 2010 and 2014, also zoning plan of Merauke Regency in 2010-2030. Furthermore, the data are processed with software LUMENS (land use planning for low emission development strategy). The result is presented descriptively. From the result, it can be concluded that based on analysis of carbon emission level in $1990-2000$, it is found 1948773.523 Ton $\mathrm{CO}_{2} /$ year with emission level per unit area in amount of 0.421 Ton $\mathrm{CO}_{2}$ eq/ha.year; observation in $2000-2005$ found emission level in amount of 6151442.314 Ton $\mathrm{CO}_{2} /$ year with emission per unit area 1.336 Ton $\mathrm{CO}_{2} \mathrm{eq} /$ ha.year; observation in 2005 - 2010 found emission level per year in amount of 41386219.77 Ton $\mathrm{CO}_{2} /$ year and emission level per unit area in amount of 9.4 Ton $\mathrm{CO}_{2}$ eq/ha.year; meanwhile, Merauke Regency's emission level in 2010 - 2014 is 61816894.268 Ton $\mathrm{CO}_{2} /$ year with emission level per unit area in amount of 13.928 Ton $\mathrm{CO}_{2}$ eq/ha.year.
\end{abstract}

Keywords: Emission, Carbon Emission, land cover.

\section{Introduction}

Climate change is a global issue which caused by the increasing of gases such as Carbon dioxide $\left(\mathrm{CO}_{2}\right)$, Methane $\left(\mathrm{CH}_{4}\right), \quad$ Nitrous oxide $\left(\mathrm{N}_{2} \mathrm{O}\right)$, Chlorofluorocarbons (CFCs) and Volatile Organic Compounds (VOCs). The gases come from energy use activity and land function change (deforestation). Indonesia committed to decrease greenhouse gases (GRK in Indonesia) emission in amount of $26 \%(0,767$ $\mathrm{GtCO}_{2}$-e) with self-effort, and 41\% (1,210 $\mathrm{GtCO}_{2}$-e $)$ with international support. Total projection of emission decrease in Business as Usual (BAU) scale is 2.95 $\mathrm{GtCO}_{2}$-e in 2020 (Indonesian Ministry of National Development Planning, 2011) [1]. Meanwhile, projection emission level based on BAU of all Riau province sectors in 2020 is for about $0,41 \mathrm{GtCO}_{2}$-e (Development Planning Agency at Sub-National Level, 2012) [2].

There are three main gases which known as greenhouse gases, they are $\left(\mathrm{CO}_{2}\right),\left(\mathrm{CH}_{4}\right)$ and $\left(\mathrm{N}_{2} \mathrm{O}\right)$. The gases considered as gas layer that traps heat wave and recently its concentrate in atmosphere are increasing twofold (IPCC, 2001). The three greenhouse gases have long lifespan such as $\mathrm{CO}_{2}$ that is the fastest increased gas and the longest lifespan (5-200 years), followed by $\mathrm{N}_{2} \mathrm{O}$ (114 years) and $\mathrm{CH}_{4}$ (12-17 years). Among three greenhouse gases, $\mathrm{N}_{2} \mathrm{O}$ has radiation capability 200 greater than $\mathrm{CO}_{2}$ (Myrold, 1999). Hence, $\mathrm{N}_{2} \mathrm{O}$ is the main greenhouse gas which caused global warming (Majumdar et al., 2000)

In Indonesia, most of greenhouse gases come from carbon dioxide, methane and nitrous oxide. Most of emission produces from forestry sector (especially because of deforestation) and energy. The second largest gas that causes global warming is methane which mostly comes from agricultural sector including animal farm activity. Merauke Regency is one of the pillars for capital of Papua Province since it's directly adjacent to Boven Digoel Regency. This condition makes Merauke has strategic role in succeeding emission level decrease since the region is within Merauke that consists of settlements and transmigration areas centered in Semangga District, Tanah Miring District, Kurik District, Jagebob District, Muting District,and Elikobel District. Relatively, concentration on Regency's physical development on North and East downtown has moved to West. Up until now, proportion of land use based on Merauke Spatial Plan with land area 4,6 million Ha shows land use 52,5\% for protection area and $47,5 \%$ for cultivation area.

\footnotetext{
*Corresponding author : untari@unmus.ac.id
} 
Based on the matter above, greenhouse gas analysis on land cover in every regional planning unit is important to be conducted in Merauke Regency. Greenhouse gas emission from land cover change is suspected come from human activity or the needs and demands of area that still in development. The consequence from the development demand is the need for new land for various development activities such as food until non-food sector. This analysis of carbon emission level on land cover change in Merauke is expected to give information about greenhouse gas emission level in Merauke Regency. Thus, it can contribute to support government policy in the obligation to decrease national emission in 2030 in amount of $29 \%$ according to Paris Agreement".

\section{Research Method}

This research uses field method by portraying the condition of land cover change in Merauke due to development activity. The used data is secondary data in form of land cover map time series data in 1990, 2000, 2005, 2010 and 2014 also Merauke zoning plan in 20102030. Furthermore, the data are processed using software LUMENS (land use planning for low emission development strategy) by using integrated approach and trade-off analysis that include: sustainable development plan, land use plan, and mitigation action plan from entire sectors.

\section{Result And Discussion}

\subsection{Change of Land Cover Map}

Based on analysis of land cover change using land cover basic map time series 1990, 2000, 2005, 2010 and 2014 which presented in Figure 1., it shows that from 1990 until 2014 land cover in Merauke has undergone significant land cover change which means carbon density level decreases.
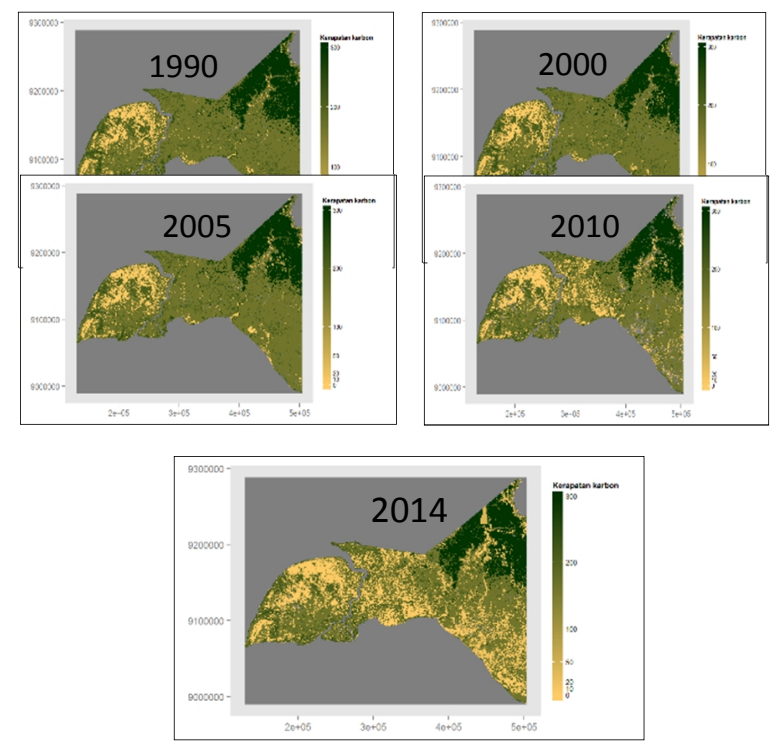

Fig. 1. Carbon density level In Merauke

\section{2 $\mathrm{CO}_{2}$ Emission Calculation in Merauke Regency}

\subsubsection{Observation in 1990-2000}

Observation in 1990-2000 shows that emission level per hectare shows 0.421 ton $\mathrm{CO}_{2}$ eq/ha.year.

Table 1. Emission Calculation Periods of 1990-2000

\begin{tabular}{|c|c|}
\hline Category & Amount \\
\hline $\begin{array}{c}\text { Total of Emission (Ton } \\
\mathrm{CO}_{2} \text { eq) }\end{array}$ & 115138606.124 \\
\hline $\begin{array}{c}\text { Total of Sequestration (Ton } \\
\mathrm{CO}_{2} \mathrm{eq} \text { ) }\end{array}$ & 95650870.892 \\
\hline Net Emission (Ton $\left.\mathrm{CO}_{2} \mathrm{eq}\right)$ & 19487735.232 \\
\hline $\begin{array}{c}\text { Emission Level (Ton } \\
\mathrm{CO}_{2} / \text { year) }\end{array}$ & 1948773.523 \\
\hline $\begin{array}{c}\text { Emission Level per-unit area } \\
\text { (Ton } \mathrm{CO}_{2} \text { eq/ha.year) }\end{array}$ & 0.421 \\
\hline
\end{tabular}

Merauke emission level observation in 1990-2000 took place on planning unit of settlement, urban area, mangrove forest area and river border. In this period, emission in Merauke tends to show in a region where there is human activity such as planning unit of settlement and urban area. Kurniawati, et all., 2012 in his study on housing development influence to carbon dioxide emission in Surabaya concludes that emission in Surabaya produces by ratio of household number per area of settlement (household $/ \mathrm{Km}^{2}$ ) and energy consumption from cooking fuel (TJ) also electric consumption (KWh). These variables are directly proportional with production of $\mathrm{CO}_{2}$ emission. Factors in housing area that contribute to production of $\mathrm{CO}_{2}$ emission is intensity of housing land use and energy consumption whether it is primary or secondary. Intensity of housing land use factor consists of household variables number per settlement area. Meanwhile, primary energy consumption factor consists of cooking fuel use such as LPG, firewood and kerosene. Also, secondary energy consumption variable is household electric consumption.

Table 1., emission level per unit area in Merauke is 0.421 ton $\mathrm{CO}_{2}$ eq/ha.year. Emission in settlement and urban area of Merauke is produced by the effort to expand settlement area so it is requiring land expansion. Yuliana, (2016) states that specific emission factor of settlement sector from cooking fuel use is classified to know carbon footprint condition. Thus, it makes emission estimation easier in a region. Besides fuel uses, emission in settlement or urban area can be caused by the needs of land in order to build new settlement. From DNPI data, 2010, show that national council of climate change mentions around $85 \%$ emission in Indonesia in 2005 is caused by land use activities. 


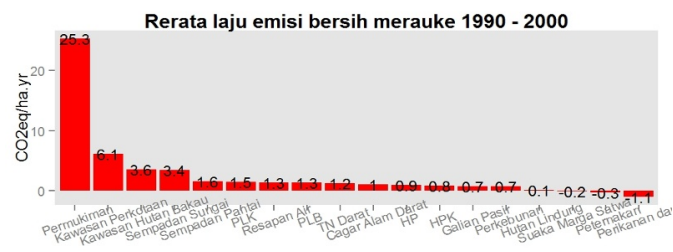

Fig. 2. Mean of Merauke Net Emission Level per plan unit

\subsubsection{Observation in 2000-2005}

Table 3. Emission Calculation in 2000-2005

\begin{tabular}{|c|c|}
\hline Category & Amount \\
\hline Total of Emission (Ton $\mathrm{CO}_{2} \mathrm{eq}$ ) & 124387508.18 \\
\hline Total of Sequestration (Ton $\mathrm{CO}_{2} \mathrm{eq}$ ) & 93630296.608 \\
\hline Net Emission (Ton $\mathrm{CO}_{2} \mathrm{eq}$ ) & 30757211.572 \\
\hline Emission Level (Ton $\mathrm{CO}_{2} /$ year) & 6151442.314 \\
\hline $\begin{array}{c}\text { Emission Level per-unit area (Ton } \\
\mathrm{CO}_{2} \text { eq/ha.year) }\end{array}$ & 1.336 \\
\hline
\end{tabular}

Observation in $2000-2005$, emission level per unit area in Merauke Regency increases to 1.33 Ton $\mathrm{CO}_{2}$ eq/ha.year from previous period which only reaches 0.42 Ton $\mathrm{CO}_{2} \mathrm{eq} /$ ha.year. Planning unit that contributes emission carbon in observation period 2000-2005 is still dominated by urban area planning which is 99 ton $\mathrm{CO}_{2} \mathrm{eq} /$ ha.year. Meanwhile, previous period observation only reaches 6.1 ton $\mathrm{CO}_{2} \mathrm{eq} /$ ha.year. Emission level in Merauke urban area always goes up. It can happen because of energy consumption pattern and needs for land in urban area always increasing. As activity center in Merauke Regency, energy use takes form of household fuel such as LPG, AC, and vehicle fumes. It is in line with the study by Yuliana, 2016 that specific emission factor is an emission factor that shows the amount of $\mathrm{CO}_{2}$ per one unit activity. Specific emission factor is based on different consumption pattern in household of urban and rural area.

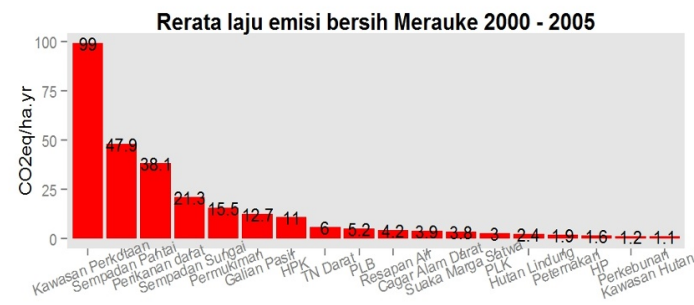

Fig. 3. Mean of Merauke Net Emission Level in 20002005 per plan unit

\subsubsection{Observation Period in 2005-2010}

Table 3. Emission Calculation in 2005-2010

\begin{tabular}{|c|c|}
\hline Category & Amount \\
\hline Total of Emission (Ton $\mathrm{CO}_{2} \mathrm{eq}$ ) & 212443788.236 \\
\hline Total of Sequestration (Ton $\mathrm{CO}_{2} \mathrm{eq}$ ) & 5512689.384 \\
\hline Net Emission (Ton $\mathrm{CO}_{2} \mathrm{eq}$ ) & 206931098.852 \\
\hline Emission Level (Ton $\mathrm{CO}_{2} /$ year) & 41386219.77 \\
\hline $\begin{array}{c}\text { Emission Level per-unit area (Ton } \\
\mathrm{CO}_{2} \text { eq/ha.year) }\end{array}$ & 9.351 \\
\hline
\end{tabular}

Observation in 2005 - 2010 carbon emission in Merauke is produced by land cover change in unit of sand digging and wetland (PLB in Indonesian). Unit of sand digging plan in Merauke emission level observation in 2005 - 2010 reach $114.8 \mathrm{co}_{2} \mathrm{eq} / \mathrm{ha}$.year, since sand digging area is used to fill the needs of building materials which are soil pile and sand. High need of digging $\mathrm{C} /$ sand digging causes high exploitation of materials. An exploitation which is not followed by rehabilitation will cause environmental damage such as high emission carbon. Area of $\mathrm{C}$ digging or sand digging in Merauke in form of soil pile is taken by change forest land cover, while sand pile and rough sand is in coastal area. Coastal area in Merauke becomes the pillar in its region. Many efforts have been done by government to reduce excessive natural resources use that possibly causes environmental issues.

Many people in this world need foods, clothes, and home. These three needs require natural resources to produce food or non-food material. Without natural resources protection, norms, and law protection, human highly possible to exploit the resources arbitrarily. Therefore, it will harm the resources and end up to environmental damage. According to Keraf (2002) [3] environmental issue is a problem of human morality and behavior. Environmental is not just technical issue.

PLB or popularly known as food crop agriculture is rice. Merauke with 44.000 ha potential wetland and it only managed 33.130 ha which is the plant target in 2018. Land opening for wetland in recent years is the main program of Merauke Regency with government support by appointed Merauke as national barns. To make it happen, land opening for wetland is done mechanically to increase plant area and rice production. The negative effect from land opening in big scale is carbon emission. Carbon emission from agricultural sector is caused by land conversion from forest to agricultural land. Land conversion especially forest area to agricultural or settlement area is the cause of greenhouse gases increase. The change is complex and affects variable that influences greenhouse gases. The change of forest area into agricultural area will change albedo area of sunlight that reaches Earth. This condition causes temperature increase especially in tropical area (Chapin et al., 2005; Feddema et al., 2005 in Suwondo et al., 2008) [4]. Other than that, loss of vegetation affects carbon cycle where absorption of $\mathrm{CO} 2$ in photosynthesis decrease and then reduced biomass and soil carbon (Gitz dan Ciais, 2003; Canadell et al., 2004; Levy et al., 2004 in Suwondo et al., 2008) [4].

Furthermore, carbon emission in wetland area happens because of chemical fertilizers and pesticides. Intensive agriculture which aims to increase food production and fulfilling local, regional, and national needs are cannot be avoided to use chemical fertilizer and pesticide. Chemical material is one of carbon emission sources. Figure 4, Mean of Merauke Net Emission Level 2005-2010 per plan unit 


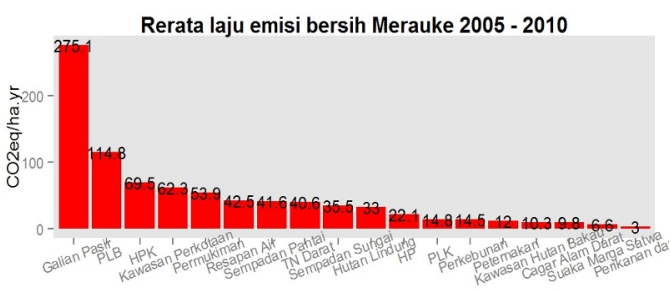

Fig. 4. Mean of Merauke Net Emission Level in 2005-2010 per plan unit.

\subsubsection{Observation in 2010-2014}

Table 4. Emission Calculation in 2010-2014

\begin{tabular}{|c|c|}
\hline Category & Amount \\
\hline Total of Emission (Ton $\mathrm{CO}_{2}$ eq) & 269926215.792 \\
\hline $\begin{array}{c}\text { Total of Sequestration (Ton } \\
\mathrm{CO}_{2} \text { eq) }\end{array}$ & 22658638.72 \\
\hline Net Emission (Ton $\mathrm{CO}_{2}$ eq) & 247267577.072 \\
\hline Emission level (Ton $\mathrm{CO}_{2} /$ year) & 61816894.268 \\
\hline $\begin{array}{c}\text { Emission level per-unit area } \\
\text { (Ton } \mathrm{CO}_{2} \text { eq/ha.year) }\end{array}$ & 13.928 \\
\hline
\end{tabular}

Observation in 2010-2014, Merauke emission level significantly increases to 13.93 Ton $\mathrm{CO}_{2} \mathrm{eq} /$ ha.year. Emission increases occur to almost all plan units. Emission level is dominated by plan unit of animal farm, agriculture, land national park, settlement, and river border. Emission level of animal farm plan unit reaches $130.4 \mathrm{Co}_{2} \mathrm{eq} /$ ha.year, while agriculture sector reaches $123.4 \mathrm{Co}_{2} \mathrm{eq} /$ ha.year. Emission activity of animal farm come from methane emission through enteric fermentation of livestock and dinitro oxide which are produced from animal manure process (Suwondo, 2014) [5]. Other than animal farm, agriculture also contributes to Merauke emission level enhancement in 2010 - 2014. It happens because of land opening from forest to new agricultural land which is oil palm plantation in Muting, Ulilin and Elikobel Districts. On global scale, land management for agriculture has contributed $15 \%$ from all greenhouse gases. Recently, it is estimated third of all carbon emissions come from land conversion (deforestation, crop change and agricultural intensification), while two-thirds of methane emission and most of nitrogen dioxide come from agricultural cultivation. The decreasing of ecosystem function also decreases plant production and environmental quality.

Intensive agriculture management, whether it is monoculture or polyculture (agroforestry) affect ecosystem change especially decreasing soil organic material (BOT in Indonesian). The more intensive a management land system, the lowest its $\mathrm{C}$ reserves (Hairiah, 2005) [6]. Generally, natural ecosystem conversion to agricultural land reduces $\mathrm{C}$ reserve and then affects biodiversity in the soil (Hairiah, 2005)[6]. Knorr et al. (2005) [7] state that the rises of temperature from ecosystem function change will cause soil microorganism decomposes organics faster and release carbon dioxide $\left(\mathrm{CO}_{2}\right)$. Based on the result above, it can be seen that period of $2010-2014$ in unit of wetland
(PLB), dryland (PLK) and animal farm also plantation contribute to the increasing of $\mathrm{CO}_{2}$ per wide area. Emission level on wetland and dryland agriculture reach 64.4 until 74,6 $\mathrm{CO}_{2}$ eq/ha.year.

Agriculture sector which becomes source of greenhouse gases is agricultural activity start from land opening until harvesting crops. According to Djajadilaga, et. al., (2009)[8] since 2006 CH4 total emission from rice field sharply increase from average 1,5 million ton per year become 1,8 million per year. By knowing the data of agriculture production activity on particular region and the data of used material amount in production activity on agricultural land, carbon emission estimation on each production activity of rice can be calculated.

Rice production activities which potentially produce carbon emission is classified into three activities, they are activity on land management, maintenance, and harvest.

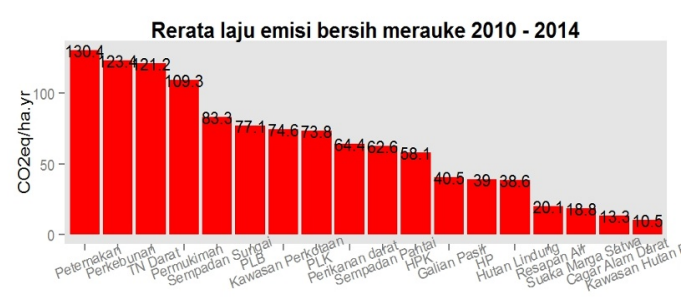

Fig. 5. Mean of Merauke Net Emission Level in 2010-2014 per plan unit.

\section{Conclusion}

The result of this research concludes that carbon density map in Merauke Regency has decreased from observation in 1990 - 2014. Meanwhile, Merauke emission level per unit area on 4 observation periods are, 0.42 ton CO2 eq/ha.year in $1990-2000$ with plan unit of settlement, urban area, and mangrove forest that dominate the carbon emission contribution; 1,34 ton $\mathrm{CO} 2 \mathrm{eq} / \mathrm{ha}$.year in $2000-2005$ with plan unit of urban area, beach border, and terrestrial fisheries which dominate carbon emission contribution; 9.35 ton $\mathrm{CO} 2$ eq/ha.year in $2005-2010$ with sand digging, PLB, and HPK dominate carbon emission contribution, and 13.93 ton CO2 eq/ha.year in 2010 - 2014 with contribution of carbon emission dominated by plan unit of animal farm, plantation, and land national park ( $\mathrm{TN}$ darat in Indonesian).

\section{Suggestions}

1. High level of carbon emission in land sector of Merauke Regency need to be decreased and reduces the causing factors of carbon emission level;

2. High level of emission on plan unit of settlement, agriculture, sand digging, and plantation need real action from many parties to make society realize the 
importance of well land use to minimize land conversion.

\section{References}

1. Badan Perencanaan Pembangunan Nasional (BAPPENAS). 2011. Strategy in Reducing $\mathrm{CO}_{2}$ Emission from Riau's Peat and Forest. Bappenas and British Council. Jakarta. (2011).

2. Badan Perencanaan Pembangunan Daerah (BAPPEDA). 2012. Rencana Aksi Daerah Penurunan Emisi Gas Rumah Kaca Provinsi Riau (RAD-GRK). Pemerintah Provinsi Riau. Pekanbaru. (2012).

3. Keraf, A.S. 2002. Etika Lingkungan. Kompas. Jakarta. 322 page

4. Suwondo. Suwarno, J, Adriman, Putuhena, J. Zainal, J, Riyadi, A. Kerjasama Sektor Kehutanan Dalam Pengurangan Emisi Gas Rumah Kaca. Makalah : Perubahan Iklim Global. PSL-IPB. Bogor. (2008)

5. Suwondo. Analisis Emisi Gas Rumah Kaca Sektor Agriculture, Forestry, and Other Land Use (AFOLU) di Propinsi Riau. Prosiding Seminar Nasional dan Rapat tahunan Bidang MIPA. p. 595-
602. (2014)

6. Hairiah, K. Biodiversitas Tanaman Sebagai Dasar Menuju Pertanian Sehat. National Seminar of 29th Anniversary of UNS. UNS Agriculture Faculty. Surakarta. (2005).

7. Knorr, W., I. C. Prentice, J. I. House dan E. A. Holland. Long-term sensitivity of soil carbon turnover to warming. Nature Vol.433, 20 January 2005, 204-205. (2005).

8. Djajadilaga, Maulyani, Aksa Tejalaksana, Heru Harnowo, Agnes Swastikarina Gusthi, Sudarmanto. Emisi Gas Rumah Kaca Dalam Angka. Asisten Deputi Urusan Data Dan Informasi Lingkungan, Kementerian Negara Lingkungan Hidup. Jakarta. Indonesia. (2009)

9. Kurniawati U.F, Rulli Pratiwi Setiawan. Pengaruh Perkembangan perumahan terhadap Emisi Karbon Diosida di Kota Surabaya. Jurnal Teknik Pomits. VO. 1, No. 1 (p 1-5). (2012).

10. Yuliana Layli, Joni Hermana dan Rachmat Boedisantoso. Determination of Specific emission Factors ofResidentioal for Corbon Footprint Estimation and Mapping in Banyuwangi Regency. Purifikasi Journal. Vol. 16, No. 1, 2016 July. (2016) 